\title{
Komparasi Berita Negatif dan Positif Mengenai Covid-19 Di Situs Detik dan Kompas
}

\author{
Joe Harrianto Setiawan ${ }^{1}$, Cintia Caroline ${ }^{2}$, Jheva Adi Ilham Akbar ${ }^{3}$ \\ ${ }^{1}$ Institut Komunikasi dan Bisnis London School of Public Relations \\ 2 Institut Komunikasi dan Bisnis London School of Public Relations \\ ${ }^{3}$ Institut Komunikasi dan Bisnis London School of Public Relations \\ Email: joe.hs@lspr.edu
}

\section{How to Cite This Article:}

Setiawan, J. H. Caroline, Cintia. Akbar, J. A. I. (2020). Komparasi Berita Negatif dam Positif Mengenai Covid-19 Pada Situs Detik dan Kompas. EXPOSE Jurnal Ilmu Komunikasi, 3(2). 146-167.

DOI: $10.33021 /$ exp.v3i2.1154

English Title: Comparison of Negative and Positive News Regarding Covid-19 On Detik and Kompas Sites.

\begin{abstract}
The paradigm of bad news is good news seems to be inherent in the world of journalism because negativity bias in the human brain makes media consumers more interested in negative news. Values in a news as a measure of the feasibility of the news usually contain conflict. An issue that is in the media spotlight around the world, namely the global health crisis due to the Covid-19 virus. This news related to Covid-19 was presented by the media in Indonesia with a lack of balance and influenced public panic. News from online media as a media innovation to compete in the business world has a role in shaping public perception. Two news sites with high popularity in Indonesia, Detik and Kompas present good and bad news about the Covid-19 pandemic. To find out how the comparison of the two sites in presenting news related to Covid-19, this study uses quantitative analysis methods. The results showed that Detik still put the Covid-19 issue as the main dish by publishing nearly 3000 news while Kompas only presented about 300 news about Covid-19. The two news sites, both Detik and Kompas, present more negative news than positive and neutral news. Detik provides 35\% positive news, 52\% negative news and 12\% neutral news. Compared to Kompas provides $34 \%$ positive news, $37 \%$ negative news and $29 \%$ neutral news. It seems that Detik site is more likely to be interested in reporting negative news.
\end{abstract}

Keywords: Good News; Bad News; Conflict; News Site; Covid-19

Abstrak Paradigma Bad news is good news tampak melekat pada dunia jurnalistik karena negativity bias pada otak manusia membuat konsumen media lebih tertarik pada berita negatif. Nilai dalam sebuah berita sebagai tolak ukur kelayakan berita tersebut biasanya mengandung konflik. Sebuah isu yang sedang menjadi sorotan media di seluruh dunia, yaitu krisis kesehatan global akibat virus Covid-19. Berita terkait Covid-19 ini disajikan media-media di Indonesia dengan kurang berimbang dan mempengaruhi kepanikan masyarakat. Berita dari media online sebagai inovasi media untuk bersaing di dunia bisnis memiliki andil dalam membentuk persepsi publik. Dua situs berita dengan popularitas yang tinggi di Indonesia, yaitu Detik dan Kompas menyajikan berita-berita negatif (bad news) maupun positif (good news) mengenai pandemi Covid-19. Untuk mengetahui bagaimana perbandingan kedua situs dalam menyajikan berita terkait Covid-19, penelitian ini menggunakan metode analisis kuantitatif. Hasil penelitian menunjukkan, 
Detik masih menempatkan isu Covid-19 ini sebagai sajian yang utama dengan menerbitkan hampir 3000 berita sedangkan Kompas hanya menyajikan berita sekitar 300 berita mengenai Covid-19. Kedua situs berita, baik Detik maupun Kompas sama-sama lebih banyak menyajikan berita negatif daripada berita positif dan netral. Pemberitaan Detik menyajikan $35 \%$ pemberitaan positif, $52 \%$ pemberitaan negatif dan $12 \%$ pemberitaan netral. Dibandingkan dengan Kompas memiliki menyajikan 34\% pemberitaan positif, $37 \%$ pemberitaan negatif dan 29\% pemberitaan netral. Terlihat situs berita Detik lebih cenderung tertarik memberitakan berita negatif.

Kata Kunci: Berita Baik; Berita Buruk; Konflik; Situs Berita; Covid-19

\section{PENDAHULUAN}

Bad news is good news adalah sebuah paradigma dalam dunia jurnalistik yang memposisikan berita yang mengandung unsur negatif terhadap sesuatu sebagai berita yang baik untuk disajikan media kepada audiensnya. Kehadiran paradigma ini menurut Bimantara (2018) bukanlah salah manusia dan bukan salah media sebagai jembatan pemberitaan, melainkan hal yang sangat logis terjadi karena manusia pada dasarnya memiliki negativity bias.

Menurut Jones-Smith (2011), negativity bias melekat pada otak manusia dan menyebabkan seseorang membuat penilaian negatif secara kritis tentang orang lain atas sedikit informasi. Negativity bias juga membuat seseorang memperhatikan kelemahan orang lain dengan sangat terperinci dan mengabaikan kelebihannya (dalam Jones-Smith 2013). Dalam konteks berita yang disajikan media, hal ini menunjukkan penyebab konsumen media lebih tertarik pada berita negatif.

Sebuah berita memiliki karakter intrinsik yang dikenal sebagai nilai berita atau news value. Nilai berita adalah tolak ukur kelayakan sebuah berita (newsworthy). Berita negatif sering muncul dalam peristiwa yang memiliki nilai berita, seperti peristiwa yang mengandung konflik, menyebabkan kerugian dan korban, serta menimbulkan kemenangan dan kekalahan (Ishwara, 2011, p.77).

Selain itu, faktor persaingan bisnis media mendorong media massa menerapkan inovasi teknologi agar mampu tetap bersaing di era bisnis. Jurnalisme media, termasuk media online, mempunyai andil dalam menguatkan persepsi publik, dan yang terjadi saat ini media justru mengedepankan aspek sensasi atau hal-hal yang dianggap menarik bagi publik demi kepentingan marketing. Konflik menjadi salah satu nilai berita yang menarik perhatian masyarakat, sehingga penonjolan konflik selalu dikedepankan, sementara solusinya dinafikan (Panuju, 2018, p.221-222).

Saat ini media massa sedang menyoroti isu krisis kesehatan global akibat suatu kelompok virus yang dapat menyebabkan penyakit pada hewan atau manusia, yaitu coronavirus secara intens. Virus ini memiliki jenis baru, yaitu Covid-19 yang dapat menyebabkan penyakit menular (WHO, 2020). Berdasarkan penelitian berjudul "Strategi Pembedahan di Era Pandemi COVID-19", virus ini pertama kali muncul di kota Wuhan, China pada akhir 2019 dan telah menyebar ke lebih dari 200 negara. Virus ini muncul di Indonesia pada Maret 2020 dan terus menyebar (Wetan \& Novianti, 2020), 
hingga 1 Juni 2020, 26.940 orang di Indonesia dikonfirmasi terinfeksi virus Covid-19 (Git Hub, Inc, 2020).

Dampak pandemi Covid-19 yang cenderung negatif sangat signifikan terasa di hampir semua sektor kehidupan masyarakat, tidak hanya di Indonesia, tetapi hampir di seluruh dunia. Setidaknya 200 negara terpapar virus Covid-19, dengan jumlah pasien yang dikonfirmasi terpapar virus Covid-19 terus meningkat setiap harinya karena karakter virus ini yang mudah menular dari satu manusia ke manusia lain (Hidayat, 2020).

Virus Corona ini dapat menyerang siapa saja, dan akan lebih menginfeksi kelompok masyarakat lanjut usia, ibu hamil, kelompok yang memiliki penyakit tertentu, perokok, dan kelompok yang memiliki daya tahan tubuh lemah (Alodokter, 2020). Pada banyak kasus, Coronavirus mempunyai gejala seperti infeksi pernapasan ringan, seperti flu. Namun, virus ini juga bisa menyebabkan infeksi pernapasan berat, seperti infeksi paru-paru atau pneumonia (Alodokter, 2020). Dikutip dari alodokter (2020), berikut ini cara penularaan Covid-19:

- Tidak sengaja menghirup percikan ludah (droplet) yang keluar saat penderita COVID-19 batuk atau bersin

- Memegang mulut atau hidung tanpa mencuci tangan terlebih dulu setelah menyentuh benda yang terkena cipratan ludah penderita COVID-19

- Kontak jarak dekat dengan penderita COVID-19.

Dari hasil kajian penelitian berjudul "Penetapan Karantina Wilayah Menurut Pandangan Legal Positivisme Dalam Rangka Pencegahan dan Pemberantasan Pandemi Coronavirus Disease (Covid-19)", ditemukan bahwa pemerintah Indonesia belum menjalankan amanat Undang-Undang Kekarantinaan Kesehatan dengan ketat, pasien positif Covid-19 dan pasien yang meninggal bertambah banyak. Hal ini disebabkan oleh terbatasnya sarana prasarana Alat Pelindung Diri (APD) dan alat-alat medis (pemeriksaan penunjang). Pandemi ini juga menghambat sektor perekonomian. Pemerintah tidak mengupayakan karantina wilayah, karena faktor ekonomi dan kekhawatiran akan ketidakmampuan pemerintah membiayai masyarakat (Setiawan, 2020).

Pada sebuah penelitian yang berjudul “Kebijakan Pemberlakuan Lockdown Sebagai Antisipasi Penyebaran Corona Virus Covid-19" bahkan menunjukkan bahwa kekhawatiran masyarakat Indonesia terhadap covid-19 cukup besar, sehingga diperlukan kebijakan pemerintah untuk melakukan Lockdown, sebagai upaya memutus mata rantai penyebaran virus corona Covid-19 (Yunus \& Rezki, 2020).

Menurut Juru Bicara Percepatan Penanganan Covid-19, Achmad Yurianto, tidak ada satupun negara yang siap menghadapi virus corona Covid-19. Maka wajar jika masyarakat menjadi panik karena tidak ada kepastian informasi (Rozie, 2020). 
Kewajaran ini sesungguhnya dapat memperburuk keadaan negara yang sedang melawan wabah serius.

Sebuah penelitian berjudul “Efek Pemberitaan Media Massa Terhadap Persepsi Masyarakat Pamekasan Tentang Virus Corona" menunjukkan media memberikan strong effect (efek yang kuat) terhadap persepsi masyarakat mengenai pencegahan penularan Virus Corona (Triyaningsih, 2020). Dari hasil penelitian terhadap kesehatan mental dari 3,686 responden dari 33 Provinsi di Indonesia, ditemukan bahwa 72 persen mengalami kecemasan dan 23 persen tidak bahagia (Yudiana, 2020). Dampak tekanan psikologis pada daya tahan tubuh justru membuat manusia semakin mudah terserang virus ini. Maka dari itu, karakter konsumsi berita mengenai pandemi Covid-19 di Indonesia menjadi sangat penting. Berita yang mengandung unsur negatif mengenai Covid-19 bagi masyarakat akan berkontribusi negatif pula bagi kesehatan masyarakat, begitu pula sebaliknya. Untuk berhasil menghadapi wabah ini, negara memerlukan halhal positif yang mendukung penanganan bersama.

Pada hasil "Analisis Berita Kesehatan di Media Massa terhadap Pelayanan Publik", menunjukkan bahwa berita mengenai kesehatan yang sering muncul berupa informasi, tanggapan, dan kebijakan, dengan arah pemberitaan yang favourable atau yang bersifat mendukung, menyetujui, atau yang menganjurkan pendapat, persoalan atau kecenderungan tertentu (Hidayat, 2015). Topik-topik pemberitaan di media baru yang ditemukan dalam penelitian berjudul "Analisis Berita Hoax Covid-19 Di Media Sosial Di Indonesia" adalah mengenai terjangkitnya Virus Corona, pengobatannya, dan perilaku sosial masyarakat dalam menghadapi virus tersebut (Sensusiyati, 2020).

Menurut Nurhallimah (2020) dalam penelitiannya berjudul “Upaya Bela Negara Melalui Sosial Distancing Dan Lockdown Untuk Mengatasi Wabah Covid-19", seiring meningkatnya jumlah manusia yang terdampak corona di seluruh dunia, informasi terkait kebenarannya pun menjadi perhatian karena ditemukannya berita-berita yang simpang siur atau hoaks, sehingga menimbulkan keresahan di masyarakat.

Berita-berita negatif mengenai pandemi covid-19 ini, mulai dari artikel terkait hal-hal medis, peningkatan jumlah pasien dan angka kematian, bahaya virus, perilaku buruk masyarakat dalam menghadapi pandemi, hingga berita terkait predksi penyebaran virus ini. Seperti sebuah artikel berjudul "Apa Penyebab Obat Penawar Covid-19 Belum juga Ditemukan?" dilansir dari laman Merdeka.com, Wakil Ketua Umum Pengurus Besar IDI, Mohammad Adib Khumaidi, menegaskan bahwa hingga saat ini belum ada temuan resmi obat untuk mengatasi Covid-19, penemuan herbal anticovid-19 yang beredar sesungguhnya hanya peningkat imun tubuh (Supriatin, 2020). Dari laman Kompas sebuah artikel berjudul "Seratusan Warga Blora Jemput Paksa Pasien Covid-19, Ganjar Minta Pemkab Awasi Ketat" juga memberitakan perilaku buruk masyarakat dalam menghadapi Coronavirus bahwa terdapat belasan kasus pasien positif Covid-19 yang dijemput paksa keluarganya dari pengobatan (Farasonalia, 2020). 
Di samping itu, ada juga berita positif mengenai pandemi Covid-19 ini, seperti pada laman Kompas.tv, diberitakan bahwa Lembaga Biomolekuler Eijkman (LBME), PT Bio Farma, dan PT Kalbe Farma sedang mengembangkan vaksin virus corona dan diperkirakan akan diuji klinis pada manusia sekitar awal 2021 (Fadhilah, 2020). Beritaberita positif terkait pandemi Covid-19 mulai dari berita mengenai ditemukannya vaksin Coronavirus, peningkatan jumlah pasien yang sembuh, kondisi tubuh manusia yang semakin lama makin bisa mengatasi virus ini, dan lain-lain.

Menurut Asmar (2020), dalam penelitiannya mengenai refleksi dan representasi pemberitaan virus corona, meskipun pada dasarnya isu virus corona dijaga secara khusus oleh seluruh dunia, perspektif ekspos media mengenai isu Covid-19 ini dianggap merugikan beberapa pihak. Berdasarkan penelitian tersebut, arus pemberitaan media atas isu ini dianggap tidak berimbang, karena secara tidak langsung membangun kesan bahwa virus corona ini pada hakikatnya adalah baik-baik saja. Hasil penelitian tersebut menunjukkan bahwa penerapan asas dari publik dan untuk publik pada media mendapat tekanan dari pihak yang berpengaruh dalam media itu. Publik di Indonesia secara garis besar bisa merespon media yang dipandang kurang netral dengan baik, meski pola pikir masyarakat masih heterogen. Media di Indonesia juga dianggap belum bisa merepresentasikan realitas sosial yang ada.

Dua situs berita yang mempunyai tingkat popularitas cukup tinggi di Indonesia, Detik dan Kompas merupakan media online yang memiliki concern terhadap perkembangan pandemi Covid-19 baik di Indonesia maupun di dunia. Berdasarkan data yang diperoleh dari Alexa.com, sebuah situs yang menyajikan data traffic dan ranking situs web, Detik dan Kompas termasuk kedalam sepuluh situs teratas di Indonesia (Alexa Internet, 2020).

Berita yang disajikan kedua situs ini sangat beragam, mulai dari berita yang dapat menimbulkan pesimisme atau kecemasan terhadap pandemi Covid-19, hingga berita yang menanamkan rasa optimisme atau harapan terhadap penanganan pandemi Covid-19. Berdasarkan uraian diatas, maka penelitian ini diarahkan pada permasalahan mengenai bagaimana perbandingan situs berita Detik dan Kompas dalam menyajikan berita terkait pandemi Covid-19. Tujuan penelitian ini adalah untuk melihat perbandingan jumlah berita yang berunsur positif dan berita yang berunsur negatif di antara dua situs berita tersebut, yaitu Detik dan Kompas agar kedepannya media-media tidak hanya mementingkan persaingan bisnis ataupun kepentingan tertentu, tetapi juga dapat mempertimbangkan sudut pandang penyajian berita yang krusial bagi kehidupan masyarakat luas.

Penelitian ini penting dilakukan karena digitalisasi telah merevolusi jurnalisme secara radikal dan membawa disrupsi melalui tiga rute, yaitu perubahan lanskap media yang mengubah karakter persaingan bisnis media karena beragamnya variasi media yang muncul, perubahan model bisnis media pemberitaan yang menyempitkan keuangan untuk produksi berita, dan perubahan norma serta cara peliputan berita 
(Ambardi, 2018, p.1). Menurut Santana (2017), kapabilitas teknis internet merupakan nilai tambah situs berita, dan digitalisasi membuat informasi mengalir secara personal dan sekejap ke seluruh masyarakat.

Media online bahkan menjadi rujukan dan alat bantu utama dalam proses komunikasi massa. Berita-berita yang disebar secara online diyakini paling efektif untuk menjangkau semua pengguna media daring dibandingkan media massa konvensional (Mahyuddin, 2019). Melalui media internet, nilai konflik dalam berita berpotensi meluas dengan kecepatan produksi dan penyebarannya karena internet cenderung membuat penggunanya berpikir impulsif dengan menyimpulkan sebelum memperoleh informasi yang lengkap (Panuju, 2018).

\section{KERANGKA TEORETIS}

\section{Berita}

Menurut Jani Yosef (2009) berita adalah laporan terkini tentang fakta atau pendapat yang penting atau menarik bagi khalayak dan disebarluaskan melalui media massa (dalam Muslimin, 2019). Berita adalah sesuatu yang nyata, peristiwa yang segar, baru saja terjadi, plus dan minus. Dari peristiwa itu, berita merentang sedikit ke masa lampau dan masa yang akan datang karena kesadaran masyarakat akan sifat sementara dari suatu keadaan (Ishwara, 2011).

Gaye Tuchman (1978) dalam bukunya "Making News" (dalam saverin \& tankard, 2005), mengatakan bahwa berita merupakan konstruksi realitas sosial. Menurut Tuchman, tindakan membuat berita adalah tindakan mengkonstruksi realita itu sendiri, bukan penggambaran realita. Berdasarkan pendapat Tuchman, berita yang disajikan media massa tidak sepenuhnya merepresentasikan fakta-fakta atau kenyataan yang sebenarnya dan apa adanya. Berita adalah produk dari sebuah usaha menyusun faktafakta menjadi sesuatu yang menarik untuk dikonsumsi. Tuchman menekankan, bahwa berita adalah sekutu bagi lembaga-lembaga yang berlegitimasi dan bahwa berita juga melegitimasi status quo (Rizki, 2016).

Pada dasarnya, suatu peristiwa selalu dilibatkan dengan manusia dan alam. Jika peristiwa alam tidak berkaitan dengan kehidupan manusia, maka peristiwa tersebut dianggap tidak penting dan tidak menarik untuk diberitakan (Tahrun, Houtman, \& Nasir, 2019).

\section{Good News dan Bad News}

Menurut Sukaca (2014), proporsi berita positif yang disajikan media-media di Indonesia tidak sebanding dengan sajian berita negatif. Informasi yang banyak diakses masyarakat Indonesia dari televisi, surat kabar, radio, dan lain-lain adalah sebagian besar informasi yang didominasi oleh berita negatif, seperti berita tentang korupsi, perampokan, pencurian, kecelakaan, perselingkuhan, perceraian, kenakalan, penggunaan narkoba, pemerkosaan, keberingasan, dan sebagainya. 
Baik sajian informasi positif maupun negatif dari media massa akan mempengaruhi audiensnya. Mengakses berita-berita positif akan menghasilkan perbuatan yang positif karena informasi positif yang terus menerus masuk ke dalam memori manusia akan menghasilkan keyakinan dan pemikiran yang positif. Maka, setiap individu harus mampu memilah informasi yang masuk kedalam pikirannya (Sukaca, 2014).

Berita baik (good news) menurut Harcup \& O'Neil dalam kerangka nilai berita yang dikemukakannya berdasarkan penyeleksian adalah berita yang mengandung "kebaikan" seperti penyelamatan dan pengobatan, sementara berita buruk (bad news) adalah berita yang mengungkapkan keburukan seperti pertengkaran atau tragedy (Santana, 2017).

Media sebagai pembawa informasi dapat mendorong situasi yang lebih maju sekaligus mengubah hal negatif menjadi positif melalui proses tertentu. Sebagai pendidik masyarakat, idealnya sebuah media tidak hanya memuat berita buruk dan negatif, tetapi juga berita positif yang mendorong, menghibur, dan menginspirasi publiknya (AR, 2018, p.16-17). Menurut AR (2018, P.31), tatkala media menyajikan informasi secara bebas, sisi positif dan negatif juga bisa muncul bersamaan.

\section{Nilai berita}

Menurut (Ishwara, 2011), dalam sebuah berita tersirat pesan yang ingin disampaikan kepada audiens media tersebut, terkandung tema dari sebuah peristiwa, dan terdapat nilai berita. Nilai berita adalah prinsip-prinsip yang menjadi sandaran profesionalisme jurnalistik. Prinsip-prinsip yang menjadi guide-line untuk mengarahkan dan mendisiplinkan awak media ketika berhadapan dengan fakta atau informasi (Sudibyo,2009).

Menurut Muslimin (2019), nilai berita merupakan unsur dan kriteria yang dijadikan sebagai ukuran terhadap fakta yang layak disajikan dan dijadikan berita untuk disebarluaskan kepada khalayak melalui media massa cetak maupun elektronik. Menurut Jani Yosef, 2009 (dalam muslimin, 2019), nilai berita juga disebut sebai nilai jurnalistik yang memiliki tiga ukuran utama dalam menentukan kelayakan suatu fakta untuk dijadikan berita, yaitu:

1. Penting; kata penting mengandung dua pengertian, pertama ialah orang penting (orang ternama) dan peristiwa penting. Media sering mengangkat peristiwa ataupun kegiatan yang dialami oleh orang penting menjadi sebuah berita.

2. Menarik; bagian kriteria umum nilai berita merupakan acuan yang dapat digunakan oleh para jurnalis, yaitu pada wartawan dan editor untuk menyeleksi berita layak disajikan atau terbit.

3. Aktual; dalam kegiatan jurnalistik, khususnya dalam proses produksi berita "aktualitas". Berkembangnya teknologi saat ini, menyebabkan aktualitas 
memiliki tingkatan aktualnya mulai dari paling aktual, cukup aktual, dan kurang aktual. Aktual berarti berita itu dipublikasikan bersamaan dengan terjadinya peristiwa itu atau langsung disebarluaskan saat peristiwa itu baru terjadi.

Menurut Ishwara (2011), peristiwa-peristiwa yang memiliki nilai berita sebagai penentu kelayakannya (newsworthy), adalah peristiwa yang mengandung konflik, bencana dan kemajuan, dampak, kemasyuran, segar, kedekatan, keganjilan, seks, dan sebagainya. Harcup \& O'Neill, 2001 (dalam Santana, 2017) mengemukakan kerangka nilai berita berdasarkan penyeleksiannya, yaitu:

1. Elit kekuasaan (power elite): berita mengenai orang atau organisasi yang berpengaruh di tengah masyarakat.

2. Selebritas (celebrity): berita mengenai orang-orang terkenal.

3. Hiburan (entertainment): berita terkait seks, bisnis pertunjukkan, kisah-kisah kemanusiaan, binatang, drama, sisipan humor, foto-foto menyentuh atau judul-judul menyengat.

4. Kejutan (surprise): berita yang mengandung elemen kejutan dan/atau kontras.

5. Berita buruk (bad news): berita yang mengungkap keburukan

6. Berita baik (good news): berita yang mengandung kebaikan

7. Besaran/kekuatan (magnitude): berita yang mengandung kekuatan terhadap sejumlah orang yang terlibat atau potensi dampaknya.

8. Relevance: berita yang relevan dengan khalayaknya.

9. Follow-up: berita yang mengandung berbagai subjek yang siap menjadi berita.

10. Newspaper agenda: berita yang mengandung kesesuaian dengan kerangka atau kesiapan dari agenda medianya.

Semua nilai berita tersebut memiliki perluasan konsep yang berkaitan dengan bentuk media, perbedaan masyarakat, dan acuannya setiap waktu (Santana, 2017).

\section{Konflik dalam Berita}

Kebanyakan konflik adalah layak berita. Konflik fisik seperti perang atau perkelahian adalah layak berita karena biasanya terdapat kerugian dan korban. Selain konflik fisik ini, debat-debat (konflik) mengenai pencemaran, reaktor nuklir dan ratusan isu yang menyangkut kualitas dari kehidupan juga mendapat tempat yang penting dalam pemberitaan (Ishwara, 2011)

Menurut Tichenor, Donohue, \& Olien (1980) dalam bukunya "Community conflict and the press" (dalam Latief \& Utud, 2017), ada tiga teknik penyajian yang dilakukan oleh media dalam peliputan konflik, yaitu:

1. Issue intensifier (memunculkan konflik): Mempertajamnya. Dalam posisi ini, media meledakkan realitas menjadi isu sehingga seluruh dimensi konflik menjadi transparan. 
2. Conflict diminisher (menenggelamkan isu konflik): Secara sengaja media meniadakan isu tersebut, terutama bila menyangkut kepentingan media bersangkutan.

3. Conflict resolution (pengarah konflik): menjadi mediator dengan menampilkan isu dari berbagai perspektif serta mengarahkan pihak yang bertikai pada penyelesaian konflik. Lewat pemberitaan, pihak yang bertikai diharapkan memahami sudut pandang orang lain.

Konflik biasanya melahirkan kemajuan dan bencana, seperti munculnya kemenangan, keberhasilan, penemuan baru, ataupun munculnya kekalahan, bencana, kerusakan, kehilangan, dan masalah baru yang menjadi nilai untuk menentukan kelayakan peristiwa tersebut sebagai berita (Ishwara, 2011).

Ketika konflik sebagai nilai berita selalu dikedepankan oleh media, kondisi ini disebut krisis sosial ataupun krisis dalam hubungan masyarakat. Menurut Panuju, krisis sosial ini merupakan proses komunikasi yang dapat menimbulkan keadaan genting karena prosesnya berjalan secara asimetris dan sulit membangun saling pengertian (mutual understanding) sehingga pesan komunikasi diterima dan direspon dengan emosional (Panuju, 2018).

\section{Situs Berita}

Media online adalah saluran komunikasi secara online berbasis telekomunikasi melalui situs web di internet (Mahyuddin, 2019). Oreskes (1999) mengatakan bahwa kelebihan internet sebagai medium adalah lebih kepada kecepatannya, bukan akurasinya. Teknologi bukan segala-galanya, dan orang-orang dibalik teknologi inilah yang lebih penting (Ishwara, 2011).

Berita online adalah media berita yang dipublikasikan melalui media daring. Ciri utama periode berita diproduksi secara online ada pada transisi media cetak manual ke media aritfisial, di mana masa ini mempengaruhi masyarakat sebagai pembaca berita secara signifikan tidak lagi bertumpu pada media cetak dan beralih ke media berita digital (Mahyuddin, 2019).

\section{METODOLOGI}

Salah satu metode utama ilmu komunikasi, yaitu metode penelitian analisis isi kuantitatif digunakan dalam penelitian ini untuk mempelajari isi media, yang dalam penelitian ini adalah media online Detik dan Kompas terkait berita-berita mengenai Covid-19 yang disajikannya. Menurut Barelson (1952), analisis isi adalah suatu teknik penelitian yang dilakukan secara objektif, sistematis, dan deskripsi kuantitatif dari isi komunikasi yang tampak (manifest) (dalam Eriyanto, 2015). 
Analisis isi kuantitatif dilakukan dengan mengukur atau menghitung aspekaspek tertentu dari isi atau konten dan disajikan secara kuantitatif secara objektif. Dengan metode analisis kuantitatif, penelitian ini mengutamakan ketepatan dalam mengidentifikasi isi (Eriyanto, 2015).

Unit analisis yang diobservasi dicatat dan dianggap sebagai data dengan dipisahkan menurut batas-batasannya, dan diidentifikasi untuk dianalisis selanjutnya (Eriyanto, 2015). Dalam penelitian ini, unit yang dianalisis adalah seluruh berita mengenai Covid-19 yang disajikan situs berita Detik dan Kompas yang paling terbaru selama satu bulan terakhir saat dilakukannya penelitian ini yaitu bulan Juni 2020 .

Pengumpulan data dilakukan dengan melakukan pencarian pada situs Detik dan Kompas dengan kata kunci "Covid-19" dan saringan rentang waktu yaitu 1 Juni 2020 hingga 30 Juni 2020 karena periode bulan tersebut merupakan bulan teraktual pada saat penelitian berlangsung di bulan Juli 2020. Setelah semua berita tersebut terkumpul, peneliti melakukan klasifikasi berita sebanyak dua kali. Pertama setiap berita berdasarkan keterkaitan isi berita terhadap isu Covid-19 yang penulis rangkum menjadi berita yang menimbulkan kecemasan/harapan, jumlah pasien, hal-hal medis, kebijakankebijakan, perilaku masyarakat, dan penanganan pemerintah.

Kedua, setiap berita digolongkan kedalam pengukuran data, di mana ukuran data yang digunakan adalah ukuran data nominal dengan kategori positif, negatif, dan netral menurut Harcup \& O'Neil (dalam Santana, 2017), di mana berita baik atau positif atau good news adalah berita yang mengandung "kebaikan" seperti penyelamatan dan pengobatan, sementara berita negatif/buruk (bad news) adalah berita yang mengungkapkan keburukan seperti pertengkaran atau tragedi, dan berita netral adalah berita yang disajikan tanpa ataupun dengan unsur keduanya, yaitu kebaikan dan keburukan.

Konstruksi kategori yang digunakan adalah nada (tone) berita di mana pemberitaan dikatakan positif jika cenderung memberikan pujian terhadap suatu kasus atau pemberitaan. Dikatakan negatif jika pemberitaan cenderung mengkritik dan bersifat netral jika di dalam pemberitaan terdapat pujian maupun kritikan. Tone berita dapat dilihat dari penilaian kalimat dalam berita yang menjadikan kalimat itu positif, negatif atau netral. (Iriantara, Yosal., Surachman, Yani, 2006), seperti:

1. Berita positif yang memberikan pernyataan mendukung seperti memuji, menyanjung, dan menyetujui.

2. Berita netral yang memberikan pernyataan seimbang atau tidak bersikap memihak.

3. Berita negatif yang memberikan pernyataan tidak mendukung seperti mencela, meremehkan, dan menolak. 


\section{HASIL DAN PEMBAHASAN}

Menurut Jani Yosef (2009) berita adalah laporan terkini tentang fakta atau pendapat yang penting atau menarik bagi khalayak dan disebarluaskan melalui media massa (dalam Muslimin, 2019). Paradigma "bad news is good news" dalam jurnalistik, di mana berita yang mengandung unsur negatif terhadap sesuatu atau seseorang sebagai berita yang baik untuk disajikan media kepada audiensnya, disebabkan oleh negativity bias yang melekat pada otak manusia sehingga sebagai konsumen media, orang lebih tertarik pada berita negatif. Sukaca (2014) mengatakan media-media di Indonesia tidak menyajikan berita yang didominasi informasi negatif dan hal ini dapat mempengaruhi audiens media tersebut.

Menurut menurut Harcup \& O'Neil, berita baik (good news) adalah berita yang isinya mengandung kebaikan, sedangkan berita buruk (bad news) mengungkapkan keburukan (Santana, 2017). Dalam sebuah berita terkandung nilai sebagai tolak ukur kelayakan berita tersebut dan peristiwa yang mengandung konflik dapat layak menjadi sebuah berita. Konflik merupakan unsur penting dalam pemberitaan karena memiliki dampak baik positif maupun negatif bagi kehidupan manusia.

Menurut Tahrun, Houtman, \& Nasir (2019), pada dasarnya suatu peristiwa selalu dilibatkan dengan manusia dan alam. Jika peristiwa alam tidak berkaitan dengan kehidupan manusia, maka peristiwa tersebut dianggap tidak penting dan tidak menarik untuk diberitakan. Pengertian ini selaras dengan berita terkait isu krisis kesehatan global terkait sekelompok virus yang dapat menyebabkan penyakit menular pada hewan atau manusia, yaitu coronavirus secara intens sedang menjadi sorotan media di seluruh dunia sejak kemunculannya pada akhir 2019 di kota Wuhan, China.

Virus ini telah menyebar ke hampir 200 negara dan masuk ke Indonesia pada Maret 2020. Virus corona menyerang siapa saja dan akan lebih menginfeksi orang-orang usia lanjut, ibu hamil, perokok, orang yang mempunyai penyakit tertentu, dan orang yang mempunyai daya tahan tubuh lemah. Tidak hanya di sektor kesehatan, virus ini juga menimbulkan kekacauan di berbagai sektor kehidupan lainnya dan tidak ada satupun negara yang siap menghadapi virus corona ini.

Munculnya virus Covid-19 sebagai sebuah pandemi merupakan bencana bagi dunia, dan beberapa hal terkait perkembangan pandemi ini, seperti penemuan vaksin, penetapan regulasi, terhambatnya perekonomian, keberhasilan pemerintah mencapai target upayanya, dan lain-lain merupakan hasil unsur konflik yang membuat berita terkait Covid-19 menjadi layak.

Bagaimanapun penyajiannya, berita mengenai Covid-19 akan mudah memenuhi nilai-nilai jurnalistik menurut Jani Yosef (2009, dalam muslimin, 2019), yaitu penting, menarik, dan actual, karena pandemi Covid-19 menyangkut hidup masyarakat luas. Selain itu, Covid-19 merupakan sebuah virus yang baru pertama kali muncul yang berpengaruh terhadap banyak sektor kehidupan lain, menimbulkan pertentangan 
dalam banyak kalangan, baru saja muncul pada akhir tahun 2019 serta terdeteksi di Indonesia pada Maret 2020, dan merupakan fenomena yang terjadi di hampir seluruh negara di dunia.

Berbagai macam berita terkait Covid-19 disajikan media-media di Indonesia dengan kurang berimbang. Media dalam menyebarkan informasi memiliki kemampuan untuk mendorong sekaligus mengubah situasi negatif menjadi positif dan sebaliknya. Oleh karena itu, kepanikan masyarakat dapat didorong oleh konsumsi berita setiap harinya, terutama berita yang bersumber dari media online yang sedang berada pada puncaknya sebagai inovasi teknologi media untuk bertahan dan meningkatkan kemampuan bersaing di dunia bisnis. Hal ini karena media online telah memiliki andil dalam membentuk persepsi publik. Secara tidak langsung berita-berita terkait Covid-19 yang disajikan media online mempengaruhi peningkatan jumlah pasien yang terinfeksi Covid-19. Berita buruk atau yang negatif dapat memberikan dampak tekanan psikologis pada daya tahan tubuh yang membuat manusia semakin mudah terserang viruscorona (Cahyono, 2020; Herlinawati, 2020).

Dalam menyajikan berita terkait Covid-19, dua situs berita yang memiliki tingkat popularitas yang tinggi di Indonesia, yaitu Detik dan Kompas menyajikan berita-berita negatif (bad news) yang dapat menimbulkan pesimisme atau kecemasan masyarakat mengenai pandemi Covid-19, maupun berita-berita positif (good news) yang menanamkan rasa optimisme atau harapan terhadap penanganan pandemi Covid-19. Berdasarkan penggolongan situs berita berdasarkan isinya menurut Deuze (2001, dalam Santana, 2017, p.231-232), Detik dan Kompas merupakan situs berita yang hanya mengonline-kan medium induknya dengan tambahan fitur interaktif, sementara isinya tidak jauh berbeda dengan berita di media cetak. Kelebihan-kelebihan yang dimiliki media online Detik dan Kompas memungkinkan banyak audiensnya menanggapi berita terkait Covid-19 secara impulsif dengan menyimpulkan sebelum memperoleh informasi yang lengkap meskipun penyajian yang dilakukan Detik dan Kompas memperhatikan bisnis media.

Berikut ini berita-berita mengenai Covid-19 yang disajikan situs Detik dan Kompas periode Juni 2020.

Tabel 1. Berita Covid-19 di Detik dan Kompas Periode Juni 2020

\begin{tabular}{|c|c|c|c|c|c|c|c|}
\hline Detik & + & - & o & Kompas & + & - & 0 \\
\hline $\begin{array}{l}\text { Yang } \\
\text { menimbulkan } \\
\text { kecemasan / } \\
\text { harapan }\end{array}$ & 108 & 184 & 7 & $\begin{array}{l}\text { Yang } \\
\text { menimbulkan } \\
\text { kecemasan / } \\
\text { harapan }\end{array}$ & 11 & 70 & 21 \\
\hline Jumlah pasien & 95 & 372 & 173 & $\begin{array}{l}\text { Jumlah } \\
\text { pasien }\end{array}$ & 35 & 55 & 9 \\
\hline Hal-hal medis & 208 & 134 & 21 & $\begin{array}{l}\text { Hal-hal } \\
\text { medis }\end{array}$ & 34 & 1 & 7 \\
\hline
\end{tabular}




\begin{tabular}{|l|c|c|c|}
\hline $\begin{array}{l}\text { Kebijakan- } \\
\text { kebijakan }\end{array}$ & 180 & 212 & 86 \\
\hline $\begin{array}{l}\text { Perilaku } \\
\text { masyarakat }\end{array}$ & 61 & 249 & 5 \\
\hline $\begin{array}{l}\text { Penanganan } \\
\text { pemerintah }\end{array}$ & 337 & 303 & 58 \\
\hline \multirow{2}{*}{ TOTAL } & $\mathbf{9 8 9}$ & $\mathbf{1 4 5 4}$ & $\mathbf{3 5 0}$ \\
\cline { 2 - 4 } & $\mathbf{3 5 , 4 0 \%}$ & $\mathbf{5 2 , 0 5 \%}$ & $\mathbf{1 2 , 5 3 \%}$ \\
\cline { 2 - 4 } & \multicolumn{3}{|c|}{$\mathbf{2 7 9 3}$} \\
\hline
\end{tabular}

\begin{tabular}{|l|c|c|c|}
\hline $\begin{array}{l}\text { Kebijakan- } \\
\text { kebijakan }\end{array}$ & 3 & 0 & 48 \\
\hline $\begin{array}{l}\text { Perilaku } \\
\text { masyarakat }\end{array}$ & 3 & 25 & 9 \\
\hline $\begin{array}{l}\text { Penanganan } \\
\text { pemerintah }\end{array}$ & 13 & 1 & 9 \\
\hline \multirow{2}{*}{ TOTAL } & $\mathbf{9 9}$ & $\mathbf{1 5 2}$ & $\mathbf{1 0 3}$ \\
\cline { 2 - 5 } & $\mathbf{2 8 , 9 6 \%}$ & $\mathbf{4 2 , 9 3 \%}$ & $\mathbf{2 9 , 0 9 \%}$ \\
\cline { 2 - 4 } & \multicolumn{3}{|c|}{$\mathbf{3 5 4}$} \\
\hline
\end{tabular}

Dari data yang ditemukan, terlihat bahwa memasuki tiga bulan Viruscorona menyebar di Indonesia, situs berita Detik masih menempatkan isu Covid-19 ini sebagai sajian yang utama dengan menerbitkan hampir 3000 berita. Sementara situs berita Kompas sudah tidak begitu menempatkan isu Covid-19 sebagai sajian utama beritanya, hal ini terlihat pada sajian berita Kompas pada periode juni 2020, dimana kompas hanya menyajikan berita sekitar 300 berita mengenai Covid-19.

Kedua situs berita, baik Detik maupun Kompas sama-sama lebih banyak menyajikan berita negatif daripada berita positif dan netral. Hal ini terlihat pada hanya sekitar 35\% pemberitaan mengenai Covid-19 berisi hal-hal yang positif, sementara sekitar 52\% nya berisi hal-hal negatif mengenai Covid-19 yang disajikan situs Detik. Perbedaan juga terlihat antara pemberitaan positif dan negatif mengenai virus corona dari situs berita Kompas, ditunjukkan dengan adanya sekitar 34\% berita yang berisi halhal positif terkait pandemi Covid-19 dan hampir 37\% berita yang berisi hal-hal yang negatif mengenai pandemi Covid-19.

Meski begitu, perbandingan berita positif dan negatif mengenai pandemi Covid19 pada Detik terlihat lebih signifikan daripada Kompas. Kedua situs berita ini juga terlihat jarang menyajikan pemberitaan yang bersifat netral. Hanya sekitar 12\% pemberitaan mengenai Covid-19 yang netral dari situs Detik dan hanya 29\% berita mengenai pandemi Covid-19 yang netral dari Kompas. Berikut adalah rincian data setuhnya yang didapatkan:

Tabel 2. Berita yang Menimbulkan Kecemasan / Harapan

\begin{tabular}{|l|c|c|c|c|}
\hline \multirow{2}{*}{ Media } & \multicolumn{2}{|c|}{ Yang menimbulkan kecemasan/harapan } & \multirow{2}{*}{ Total } \\
\cline { 2 - 4 } & + & - & $\mathbf{O}$ & \\
\hline \multirow{2}{*}{ Detik } & 108 & 184 & 7 & 299 \\
& $(36,12 \%)$ & $(61,53 \%)$ & $(2,34 \%)$ & $(10,70 \%)$ \\
\hline \multirow{2}{*}{ Kompas } & 11 & 70 & 21 & 102 \\
& $(10,78 \%)$ & $(68,62 \%)$ & $(20,58 \%)$ & $(28,81 \%)$ \\
\hline
\end{tabular}

Berita mengenai perkembangan Covid-19 yang menimbulkan kecemasan sedikit lebih banyak disajikan oleh situs berita Kompas daripada situs berita Detik, di mana Kompas memang paling banyak menyajikan berita yang dapat menimbulkan kecemasan ataupu harapan diantara tema-tema berita Covid-19 lainnya. 
Tabel 3. Berita Mengenai Jumlah Pasien

\begin{tabular}{|l|c|c|c|c|}
\hline \multirow{2}{*}{ Media } & \multicolumn{3}{|c|}{ Jumlah pasien } & \multirow{2}{*}{ Total } \\
\cline { 2 - 4 } & + & - & O & \\
\hline Detik & $95(14,84 \%)$ & $372(58,12 \%)$ & $173(27,03 \%)$ & $640(22,91 \%)$ \\
\hline Kompas & $35(35,35 \%)$ & $55(55,55 \%)$ & $\begin{array}{c}9 \\
(9,09 \%)\end{array}$ & $99(27,96 \%)$ \\
\hline
\end{tabular}

Berita terkait jumlah pasien terinfeksi Covid-19 adalah tema berita yang paling banyak kedua yang disajikan oleh kedua situs berita baik Detik maupun Kompas. Lebih dari sebagian berita mengenai jumlah pasien Covid-19 berisikan hal-hal negatif disajikan oleh situs Detik dan Kompas. Informasi mengenai jumlah pasien terinfeksi virus corona yang bertambah lebih ditonjolkan kedua situs berita ini dan hal ini menunjukkan bahwa penyebaran virus ini cenderung terus bertambah, baik di Indonesia maupun di dunia.

Tabel 4. Berita Terkait Hal-Hal Medis

\begin{tabular}{|l|c|c|c|c|}
\hline \multirow{2}{*}{ Media } & \multicolumn{3}{|c|}{ Hal-hal medis } & \multirow{2}{*}{ Total } \\
\cline { 2 - 4 } & + & - & O & \\
\hline \multirow{2}{*}{ Detik } & $208(57,30 \%)$ & $134(35,91 \%)$ & 21 \\
$(5,78 \%)$ & $363(12,99 \%)$ \\
\hline Kompas & $34(80,95 \%)$ & 1 & 7 & $42(11,86 \%)$ \\
& & $(2,38 \%)$ & $(16,66 \%)$ & \\
\hline
\end{tabular}

Terkait hal-hal medis dalam perkembangan virus corona, kedua situs berita lebih banyak menyajikan berita yang berisi hal-hal positif dengan perbandingan yang cukup signifikan. Lebih dari setengah berita mengenai hal-hal medis untuk virus corona bersifat positif disajikan oleh situs berita Detik dan Kompas. Informasi mengenai halhal medis yang disajikan kedua situs berita ini sebagian besar berkaitan dengan obatobatan, vaksin, gejala infeksi, dan alat-alat medis untuk penanganan virus ini.

Tabel 5. Berita Mengenai Kebijakan

\begin{tabular}{|l|c|c|c|c|}
\hline \multirow{2}{*}{ Media } & \multicolumn{3}{|c|}{ Kebijakan-kebijakan } & \multirow{2}{*}{ Total } \\
\cline { 2 - 4 } & + & - & O & \\
\hline Detik & $180(37,65 \%)$ & $212(44,35 \%)$ & $86(17,99 \%)$ & $478(17,11 \%)$ \\
\hline Kompas & 3 & 0 & $48(94,11 \%)$ & $51(14,40 \%)$ \\
\hline
\end{tabular}

Dalam memberitakan kebijakan-kebijakan yang diberlakukan untuk menangani pandemi Covid-19, situs Kompas cenderung bersifat netral. Hal ini ditunjukkan dengan sekitar 94\% dari berita terkait kebijakan-kebijakan disajikan situs Kompas secara netral 
tanpa adanya berita mengenai kebijakan yang berisi hal-hal negatif. Sementara itu, situs Detik hampir setengah dari semua berita terkait kebijakan-kebijakan dalam mengatasi pandemi Covid-19, yaitu sekitar $44 \%$ cenderung berisi informasi-informasi yang bersifat negatif, seperti mengenai kebijakan yang diberlakukan karena penyebaran Covid-19 yang memburuk. Hal ini disebabkan karena memang berdasarkan berita terkait jumah pasien, penyebaran virus Covid-19 ini terus meluas dan bertambah, baik di Indonesia maupun di dunia.

Tabel 6. Berita Mengenai Perilaku Masyarakat

\begin{tabular}{|l|l|l|l|l|}
\hline \multirow{2}{*}{ Media } & \multicolumn{3}{|c|}{ Perilaku masyarakat } & \multirow{2}{*}{ Total } \\
\cline { 2 - 5 } & + & - & 0 & \\
\hline \multirow{2}{*}{ Detik } & $61(19,36 \%)$ & $249(79,04 \%)$ & $\begin{array}{l}3 \\
(1,58 \%)\end{array}$ & $315(11,27 \%)$ \\
\hline Kompas & 3 & 25 & 9 & $37(10,45 \%)$ \\
\hline
\end{tabular}

Berita terkait bagaimana perilaku masyarakat dalam menghadapi pandemi Covid-19 adalah informasi yang paling sedikit kedua yang disajikan oleh kedua situs, Detik dan Kompas. Namun, sudut pandang berita mengenai perilaku masyarakat yang disajikan kedua situs ini sangat berbanding terbalik. Perilaku masyarakat dalam menghadapi pandemi Covid-19 yang tercermin dalam pemberitaan di situs Detik cenderung bersifat negatif dengan persentase sekitar 79\% dari semua berita terkait perilaku masyarakat terhadap pandemi Covid-19, seperti berita bahwa ada masyarakat yang membawa kabur pasien Covid-19; ada kelompok masyarakat yang menolak mengikuti test Covid-19; ada pasien yang kabur dari rumah sakit; masyarakat tidak mengikuti kebijakan memakai masker, social distancing; dan lain-lain. Situs Kompas juga cenderung bersifat negatif dengan presentase 67\% dalam menyajikan berita terkait perilaku masyarakat terhadap pandemi Covid-19.

Tabel 7. Berita Terkait Penanganan Pemerintah

\begin{tabular}{|l|l|l|l|l|}
\hline \multirow{2}{*}{ Media } & \multicolumn{3}{|c|}{ Penanganan pemerintah } & \multirow{2}{*}{ Total } \\
\cline { 2 - 4 } & + & - & O & \\
\hline \multirow{2}{*}{ Detik } & $337(48,28 \%)$ & $303(43,40 \%)$ & $\begin{array}{l}58 \\
(8,30 \%)\end{array}$ & $698(24,99 \%)$ \\
\hline Kompas & $13(56,52 \%)$ & $\begin{array}{l}1 \\
(4,34 \%)\end{array}$ & $\begin{array}{l}9 \\
(39,13 \%)\end{array}$ & $\begin{array}{l}23 \\
(6,49 \%)\end{array}$ \\
\hline
\end{tabular}

Informasi mengenai bagaimana penanganan pemerintah dalam menghadapi Covid-19 adalah kategori informasi yang paling sedikit yang disajikan oleh situs Kompas dengan persentasi hanya sekitar $6 \%$ dari keseluruhan jumlah berita mengenai Covid-19 yang disajikannya. Berbanding terbalik dengan situs berita Detik yang justru paling banyak menyajikan berita terkait bagaimana penanganan pemerintah dalam 
menghadapi pandemi ini. Selain hal-hal medis, berita terkait bagaimana Pemerintah menangani pandemi Covid-19 ini juga cenderung disajikan secara baik dengan informasi-informasi positif oleh kedua situs. Meskipun selisih perbandingan antara berita mengenai penanganan pemerintah yang bersifat positif dengan negatif yang disajikan Detik tidak begitu signifikan, hal ini pun menunjukkan bahwa dalam memberitakan bagaimana penanganan pemerintah dalam menghadapi pandemi Covid19, Detik cukup berimbang.

\section{KESIMPULAN}

Dari pembahasan diatas, dapat ditarik kesimpulan bahwa perbandingan antara bad news dan good news terkait pandemi Covid-19 yang disajikan situs berita Kompas sama-sama lebih banyak menyajikan berita negatif walau dengan sejumlah perbedaan. Hasil penelitian menunjukkan dalam menyajikan berita mengenai pandemi Covid-19, situs Detik cenderung menyajikan berita buruk (bad news) mengenai pandemi Covid-19 dengan informasi-informasi yang bersifat negatif. Dengan kata lain, situs Detik masih menggunakan paradigma "bad news is good news" dalam penyajian berita terkait pandemi Covid-19, dimana hal ini dapat menimbulkan emosi negatif seperti kekhawatiran, rasa cemas, dan ketakutan pada masyarakat Indonesia terhadap virus corona yang secara tidak langsung memberikan dampak buruk bagi kesehatan masyarakat, serta memperburuk keadaan pandemi Covid-19 di Indonesia.

Hal ini menunjukkan bahwa istilah "bad news is good news" masih berlaku karena media lebih mengedepankan berita-berita negatif daripada berita-berita positif. Peneliti menyarankan agar media menyajikan berita secara berimbang terutama berita mengenai isu krisis yang tengah dihadapi negara dan dunia. Media sebaiknya tidak mengutamakan keperluan bisnisnya dan tetap berada pada prinsip untuk mengabdi pada kepentingan bangsa, agar media dapat berperan dalam membantu penanganan suatu masalah atau bencana dan tidak memperburuk keadaan dan kesejahteraan negara.

Untuk penelitian selanjutnya yang akan dilakukan terkait komparasi berita disarankan agar meneliti bagaimana sajian berita mengenai Covid-19 di media lainnya selain Detik dan Kompas. Tidak hanya situs berita online, informasi-informasi mengenai Covid-19 juga tersebar melalui saluran komunikasi lainnya, seperti media sosial. Selain itu, penelitian selanjutnya juga disarankan untuk meneliti berbagai isu lain yang juga berkontribusi besar terhadap kehidupan bangsa dan negara.

\section{REFERENSI}

Alexa Internet. (2020). Top Sites in Indonesia. Retrieved from Alexa.com: https://www.alexa.com/topsites/countries/ID

Alodokter. (2020, Juli 3). Virus Corona. Retrieved from Alodokter Web site: https://www.alodokter.com/virus-corona 
Ambardi, K. (2018). Disrupsi Digital dan Kualitas Jurnalisme Online Indonesia. Di dalam G. D. Ambard, K. Parahita, G., D. Lindawati, L. \& Sukarno, A., W. (Ed) Kualitas Jurnalisme Publik di Media Online: Kasus Indonesia. (1). Yogyakarta, Indonesia: UGM Press.

AR, M., F. (2018). Sejarah Media: Transformasi, Pemanfaatan, dan Tantangan. Malang, Indonesia: UB Press.

Asmar, A. (2020). Media Dan Realitas Sosial: Refleksi Dan Representasi Pemberitaan Virus Corona. Al-Din: Jurnal Dakwah dan Sosial Keagamaan, 6(1), DOI: https://doi.org/10.35673/ajdsk.v6i1.851.

Bimantara, B. (2018, Mei 27). Paradigma: Bad News is Bad atau Good News? Diperoleh pada 4 July 2020, dari https://kumparan.com/bob-bimantara/paradigmabad-news-is-bad-atau-good-news/full

Cahyono, B. (2020, Mei 2020). Sebaran Informasi Covid-19 Berdampak Buruk pada Psikologis Seseorang, Ini Penjelasannya. Diperoleh pada 5 July 2020, dari https://www.ayojakarta.com/read/2020/05/02/16791/sebaran-informasicovid-19-berdampak-buruk-pada-psikologis-seseorang-ini-penjelasannya

Fadhilah. (2020, Juli 8). Vaksin Corona Merah Putih Buatan Indonesia Diproduksi untuk 70 Persen Jumlah Penduduk. Diperoleh pada 10 July 2020, dari https://www.kompas.tv/article/92512/vaksin-corona-merah-putih-buatanindonesia-diproduksi-untuk-70-persen-jumlah-penduduk

Farasonalia, R. (2020, Juni 18). Seratusan Warga Blora Jemput Paksa Pasien Covid-19, Ganjar Minta Pemkab Awasi Ketat. Diperoleh pada 10 July 2020, dari https:/ / regional.kompas.com/read/2020/06/18/10550851/seratusan-wargablora-jemput-paksa-pasien-covid-19-ganjar-minta-pemkab-awasi?page=all

GitHub, Inc. (2020, Juni 1). JHU CSSE COVID-19 Data. Diperoleh pada 1 Juni 2020, dari https://github.com/CSSEGISandData/COVID-19

Herlinawati, M. (2020, Maret 19). Psikolog: Panik dan stress sebabkan daya tahan tubuh menurun. Diperoleh pada 5 July 2020, dari https://www.antaranews.com/berita/1366982/psikolog-panik-dan-stresssebabkan-daya-tahan-tubuh-menurun

Hidayat, R. (2020, April 8). Ini Penyebab Corona COVID-19 Sangat Mudah Menyerang Sel Manusia. Diperoleh pada 1 Juni 2020 dari https:/ / www.liputan6.com/bola/read/4222013/ini-penyebab-corona-covid19-sangat-mudah-menyerang-sel-manusia

Hidayat, T. W. (2015). Analisis Berita Kesehatan di Media Massa terhadap Pelayanan Publik. Jurnal Simbolika, 137-152, 1(2), DOI: https://doi.org/10.31289/simbollika.v1i2.208 
Iriantara, Yosal., dan Surachman, Yani. (2006). Public Relations Writing:Pendekatan Teoritis dan Praktis. Bandung: Simbiosa Rekatama Media.

Iskandarsyah, A. (2020). Information provision about Covid-19, Health Behaviors and Mental Health in Indonesia. DOI 10.17605/OSF.IO/QU3EC.

Ishwara, L. (2011). Jurnalisme Dasar. Jakarta, Indonesia: PT Kompas Media Nusantara.

Jones-Smith, E. (2013). Strengths-Based Therapy: Connecting Theory, Practice and Skills. California, Amerika: SAGE Publications.

Kurnia, S., S. (2017). Jurnalisme Kontemporer Edisi Kedua. Jakarta, Indonesia: Yayasan Pustaka Obor.

Latief, R. \& Utud, Y. (2017). Kreatif Siaran Televisi (Hard News, Soft News, Drama, NonDrama). Jakarta, Indonesia: Kencana.

Mahyuddin, M. A. (2019). Sosiologi Komunikasi: (Dinamika Relasi Sosial di dalam Era Virtualitas). Makassar, Indonesia: Penerbit Shofia.

Muslimin, K. (2019). Jurnalistik Dasar (Jurus jitu menulis berita, feature biografi, artikel populer dan editorial). Yogyakarta, Indonesia: UNISNU.

Nurhalimah, N. (2020). Upaya Bela Negara Melalui Sosial Distancing Dan Lockdown Untuk Mengatasi Wabah Covid-19. SSRN, DOI: https://dx.doi.org/10.2139/ssrn.3576405.

Oetama, J. (2001). Pers Indonesia: berkomunikasi dalam masyarakat tidak tulus. Jakarta, Indonesia: Penerbit Buku Kompas.

Panuju, R. (2018). Pengantar Studi (Ilmu) Komunikasi: Komunikasi sebagai Kegiatan Komunikasi sebagai Ilmu. Jakarta, Indonesia: Kencana.

Rahayu, R. N. \& Sensusiyati. (2020). Analisis Berita Hoax Covid -19 Di Media Sosial di Indonesia. Intelektiva: Jurnal Ekonomi, Sosial, \& Humaniora, 60-73, 1(9), ISSN: 2686-5661.

Rezki, A. \& Yunus, N. R. (2020). Kebijakan Pemberlakuan Lock Down Sebagai Antisipasi Penyebaran Corona Virus Covid-19. Salam: Jurnal Sosial dan Budaya Syar-i, 7 (3), DOI: $10.15408 /$ sjsbs.v7i3.15083.

Rizki, J. W. S. (2016). Kepemilikan Media dan Ideologi Pemberitaan. Yogyakarta, Indonesia: Deepublish.

Rozie, F. (2020, Juni 23). Pemerintah: Tak Ada Negara Siap Hadapi Covid-19, Wajar Timbul Kepanikan. Diperoleh pada 5 July 2020, dari https:/ / www.merdeka.com/ peristiwa/ pemerintah-tak-ada-negara-siaphadapi-covid-19-wajar-timbul-kepanikan.html

Santana, Septian.2017. Jurnalisme Kontemporer. Jakarta: Yayasan Pustaka Obor Indonesia. 
Setiawan, Y. I. S. (2020). Penetapan Karantina Wilayah Menurut Pandangan Legal PositivismeDalam Rangka Pencegahan dan Pemberantasan Pandemi CoronavirusDisease (Covid)-19. Doi: 10.31219/osf.io/zfg6x.

Sudibyo, A. (2009). Kebebasan semu: penjajahan baru di jagat media. Jakarta, Indonesia: PT Kompas Media Nusantara.

Sukaca, A. (2014). The 9 Golden Habits for Brighter Muslim. Yogyakarta, Indonesia: Bunyan.

Supriatin. (2020, April 2). Apa Penyebab Obat Penawar Covid-19 Belum juga Ditemukan?. Diperoleh pada 10 July 2020, dari https://www.merdeka.com/ peristiwa/apa-penyebab-obat-penawar-covid19-belum-juga-ditemukan.html

Tahrun. Houtman. \& Nasir, M. (2019). Keterampilan Pers Dan Jurnalistik Berwawasan Jender. Yogyakarta, Indonesia: Deepublish

Triyaningsih, H. (2020). Efek Pemberitaan Media Massa Terhadap Persepsi Masyarakat Pamekasan Tentang Virus Corona. Meyarsa: Jurnal Ilmu Komunikasi dan Dakwah, 1(1) DOI: http://dx.doi.org/10.19015/meyarsa.v1i1.3222.

Wetan, N. G. A. A. M. Y. \& Novianti, P. A. (2020). Strategi Pembedahan di Era Pandemi COVID-19. Jurnal Bedah Nasional, 11-14, 4(1), DOI: https://doi.org/10.24843/JBN.2020.v04.is01.p03.

WHO. (2020). QA for Public. Retrieved from WHO: https://www.who.int/indonesia/news/novel-coronavirus/qa-for-public 